\title{
Preliminary investigation of the formation age and chemical characterization of the tropical peat in the middle Sepik Plain, northern Papua New Guinea
}

\author{
Eisuke Ono ${ }^{1 *}$, Mitsutoshi Umemura ${ }^{2}$, Takuya Ishida ${ }^{2}$ and Chisato Takenaka ${ }^{2}$
}

\begin{abstract}
Seven gouge cores in the middle Sepik Plain (northern Papua New Guinea) were bored to clarify the depositional age and the chemical characteristics of the tropical peat. The weakly-acidic peat layer (3-4 m thick) is distributed around the south bank of the Blackwater Lakes. The peat layer consists mainly of sago palm and grass remains within a mineral matrix of very fine sand and clay. Radiocarbon dating indicates that the peat's formation had commenced by 3,710-3,560 cal BP. Nitrogen and exchangeable potassium reach their highest values in the upper $60 \mathrm{~cm}$ of the peat column. Conversely, exchangeable sodium, calcium and magnesium, as well as carbon, increase their values with depth in the peat. These differences in the exchangeable cations' contribution suggest changes in the plant species, which were decomposed during the peat's formation.
\end{abstract}

Keywords: Blackwater Lakes; Papua New Guinea; Sago palm; Sepik River; Tropical peat

\section{Background}

Carbon dioxide storage in tropical peatlands has recently attracted significant international attention. Carbon dioxide emission from deforested tropical peatlands is a very important and controversial issue, in the context of global warming [1,2]. Tropical peatlands are widely distributed in south-east Asia and Oceania, but only a limited area has been studied, with regard to carbon dioxide storage and emission problems. The detailed distribution, formation process and chemical properties of tropical peats have been clarified in Indonesia and Malaysia (e.g. [3-6]). However, there have been relatively few studies of tropical peatlands in Oceania. Oceania's largest peatland area, estimated at 290,000500,000 ha $[7,8]$, is situated in Papua New Guinea.

Previous research on Papua New Guinea included studies of highland peat in the mountain areas $[9,10]$ and a few geomorphologic studies of the main peatlands, which are distributed in the floodplains of the Fly and

\footnotetext{
* Correspondence: ono@ed.niigata-u.ac.jp

${ }^{1}$ School of Education, Niigata University, 8050 Ikarashi-Ninocho, Nishi-ku, Niigata 950-2181, Japan

Full list of author information is available at the end of the article
}

Sepik Rivers [11,12]. Additional geological data in these regions is expected to clarify the details of tropical peat distribution, as well as the floodplains' geomorphological development.

In the present study, an array coring survey was conducted around the south bank of the Blackwater Lakes, in the middle Sepik Plain. The peat layer's thickness, its depositional age and chemical characteristics were identified to determine the formation process and the distribution range of tropical peats in the inland floodplains of Papua New Guinea.

\section{Study area}

The study area comprises the water catchment of the Sepik River, extending over $77,700 \mathrm{~km}^{2}$ within a tectonic basin [13], in the northern part of Papua New Guinea (Figure 1). The river $(1,126 \mathrm{~km}$ total length) flows eastwards through the basin and discharges into the Bismarck Sea [14]. The Sepik basin is filled with alluvial sediments originating from the Pleistocene rocks, which form the nearby mountains [15].

The physical environment of the middle Sepik Plain is divided into three land systems: 'Sanai', 'Pandago' 




Figure 1 Index map displaying the topography around the Sepik lowland.

and 'Kabuk' [16]. The Sanai component corresponds to floodplain swamps with minor low levees, scrolls and oxbow lakes; subject to severe flooding. These areas contain organic soils, alluvial black clays and plastic heavy clay and young alluvial soils covered with mixed grass. Phragmites swamps, in particular, also include minor herbaceous swamp vegetation. Such areas are widespread along the Sepik River. In contrast, the Kabuk and Pandago components are distributed on the edge of the flood plain. The Kabuk component refers to permanent floodplain swamps, consisting of organic soils and plastic, heavy clay, young alluvial soils, which cover the sago palmPhragmites swamps. The Pandago component corresponds to seasonally-inundated floodplain swamps. These are very poorly drained and include swampy, plastic, heavy clay, young alluvial soils, occasionally with organic soils that are covered by sago palm forests and sago palm swamps.

Although the study area is located in a tropical region, rainfall is generally not heavy, and the monthly averages range from 203 to $356 \mathrm{~mm}$ in the wettest month, i.e. between October and March, to 51-127 mm in the driest month, i.e. between March and October. Rainfall causes water-level fluctuations in the rivers and lakes $[17,18]$.

The field surveys conducted for the purposes of the present study focused on the south bank of the Blackwater Lakes, about $150 \mathrm{~km}$ upwards from the river mouth and about $10 \mathrm{~m}$ above sea level (Figure 2). The floodplain

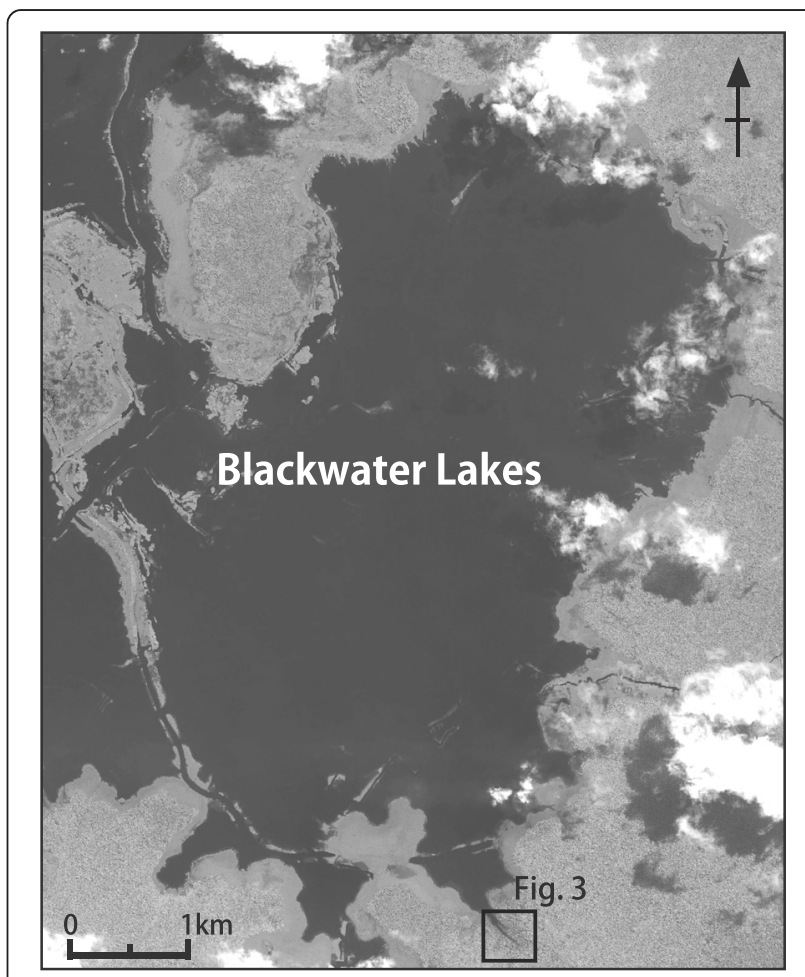

Figure 2 Satellite image of the eastern part of the Blackwater Lakes. 
consists mainly of meander belts, backmarsh, abandoned channels and lakes. Most of the lakes are separated by the meander belts of a Sepik tributary. The Blackwater Lakes are vast lakes in the middle Sepik Plain, which expand to approximately $60 \mathrm{~km}^{2}$ during the rainy season. A village named 'Kraimbit' is located on the south bank of the lake. The typical micro-landscape of the middle Sepik Plain is observed on the southern bank of the Black Water Lakes. It can be divided into three main areas, based on their physical environment: permanent floodplain swamps, seasonally-inundated floodplains covered by grass (residential quarter and garden) and seasonally-inundated flood-plains covered by sago palm, corresponding to Sanai, Kabuk and Pandago.

\section{Methods}

A geological transect, from Blackwater Lakes to Sago Forest, was realised, extracting seven gouge cores

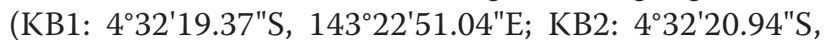

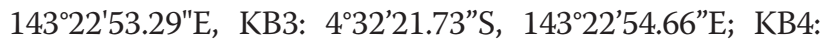
$4^{\circ} 32^{\prime} 18.87^{\prime \prime S}$, $143^{\circ} 22^{\prime} 50.43^{\prime \prime} \mathrm{E}$; KB5: 432'20.94"S, $143^{\circ}$ 22'53.29”'E; KB7: $4^{\circ} 32^{\prime} 23.32^{\prime \prime S}, 1^{\circ} 3^{\circ} 22^{\prime} 55.14 ”$ "E; KB8: $\left.4^{\circ} 32^{\prime} 25.55^{\prime \prime} \mathrm{S}, 143^{\circ} 22^{\prime} 56.31^{\prime \prime} \mathrm{E}\right)$ at $20-60 \mathrm{~m}$ intervals along the transect, to determine the distribution of the peat layer. In addition, observations on the village outcrops were recorded. The $250 \mathrm{~m}$ transect crosses the floodplain, from north to south, centred at Kraimbit village. The cores are $25 \mathrm{~mm}$ in diameter and range from 1.0 to $4.5 \mathrm{~m}$ in depth. The sedimentary features of the cores were logged in the field. The relative elevation of each coring site was determined using an automatic level, based on the water level of the Blackwater Lakes at 6:00 P.M. on 21 August 2011.

Samples from two cores were radiocarbon-dated using the accelerator mass spectrometry (AMS) method. The ages were calibrated using Calib5.0 [19] and were converted from radiocarbon years (y BP) to calendar years (cal BP) using INTCAL04 [20].

From core KB1, 38 samples were collected for chemical analysis, at 0.1-metre depth-intervals. They were air-dried and then sieved through a 2-mm mesh. Un-decomposed pieces of wood, whenever present, were removed from the samples, in this step. Total carbon (TC) and total nitrogen (TN) content, as well as their ratio $(\mathrm{C} / \mathrm{N})$ were measured through a $\mathrm{CN}$ analyser (CN Corder MT-700, Yanaco) in the air-dried fine samples. The $\mathrm{pH}$ was determined by a glass electrode (pH/COND metre D-54, HORIBA) in suspension (the sample: deionized water $=1: 10$ at mass ratio) after stirring for one hour. To determine the exchangeable cation contents, in the samples, they were stirred for one hour with $1 \mathrm{M}$ ammonium acetate solution ( $\mathrm{pH}$ 7) (sample: solution $=1: 20$ ), and subsequently filtered through a $0.45-\mu \mathrm{m}$ membrane-filter (A045A025A, ADVANTEC, Tokyo, Japan). The sodium (Na), potassium (K), calcium
(Ca) and magnesium $(\mathrm{Mg})$ concentrations in the filtrates were then analysed using an ICP-AES (IRIS ICAP, Nippon Jarrell Ash).

\section{Results}

\section{Stratigraphy and radiocarbon ages}

The transected deposits are mainly composed of a 3$4 \mathrm{~m}$ thick peat layer (Figures 3 and 4). The peat layers consist of partially-decomposed organic matter and contain sago palm and grass remains in a mineral matrix of very fine sand and clay. Inorganic silty clay was located under the peat layer at coring sites KB1, KB3, KB4 and KB5. In addition, inorganic fine sand was detected under the silty clay at coring site KB5. The peat layer's base is sharp and clear, wherever it is located. The peat layer has a greater thickness on the inland side. Three dates, 3,710-3,560 cal BP, 3,620-3,440 cal BP and 2,870$2,760 \mathrm{cal} \mathrm{BP}$, were obtained from the lower and the middle part of the peat layer (Table 1).

The peat layer was also detected beyond the studied transect, in river outcrops and artificial water-courses in the village. One particular artificial water-course, approximately $200 \mathrm{~m}$ south of the coring site KB1, presented the three-dimensional sedimentary characteristics of the peat layer (Figure 5), clearly indicating the progressive soil formation in the surface layer.

\section{Chemical characterization}

The results of the chemical analysis on the samples of core $\mathrm{KB} 1$ are presented in Figure 6. The average $\mathrm{pH}$ value is 5.73 in the silty clay (G.L. -4.00 to $-3.58 \mathrm{~m}$ ) and 4.40 in the peat layer (G.L. -3.58 to $0.00 \mathrm{~m}$ ); the peat is weakly acidic. The total carbon-to-total nitrogen values range between 19.7 and 78.2, and are classified broadly

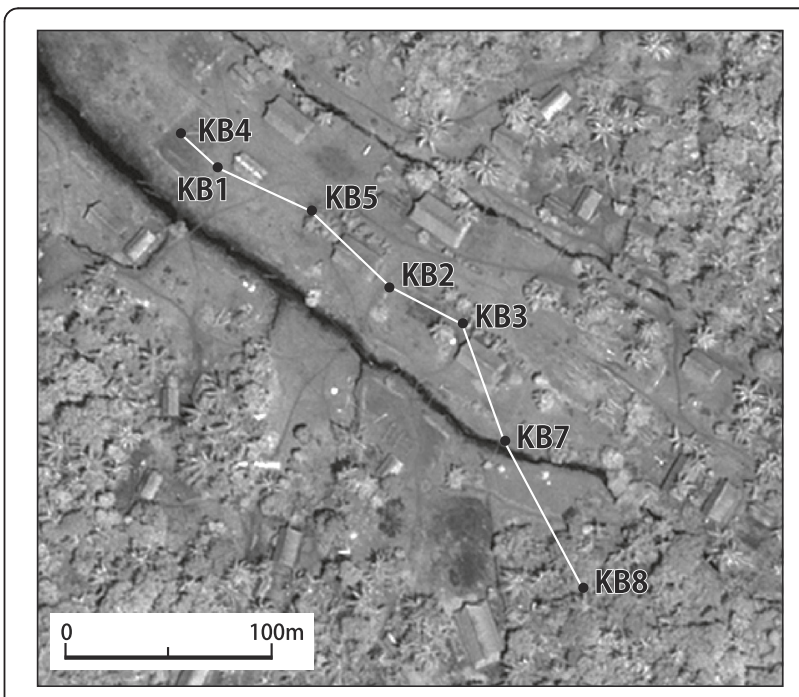

Figure 3 Map showing the coring sites in Kraimbit village. 


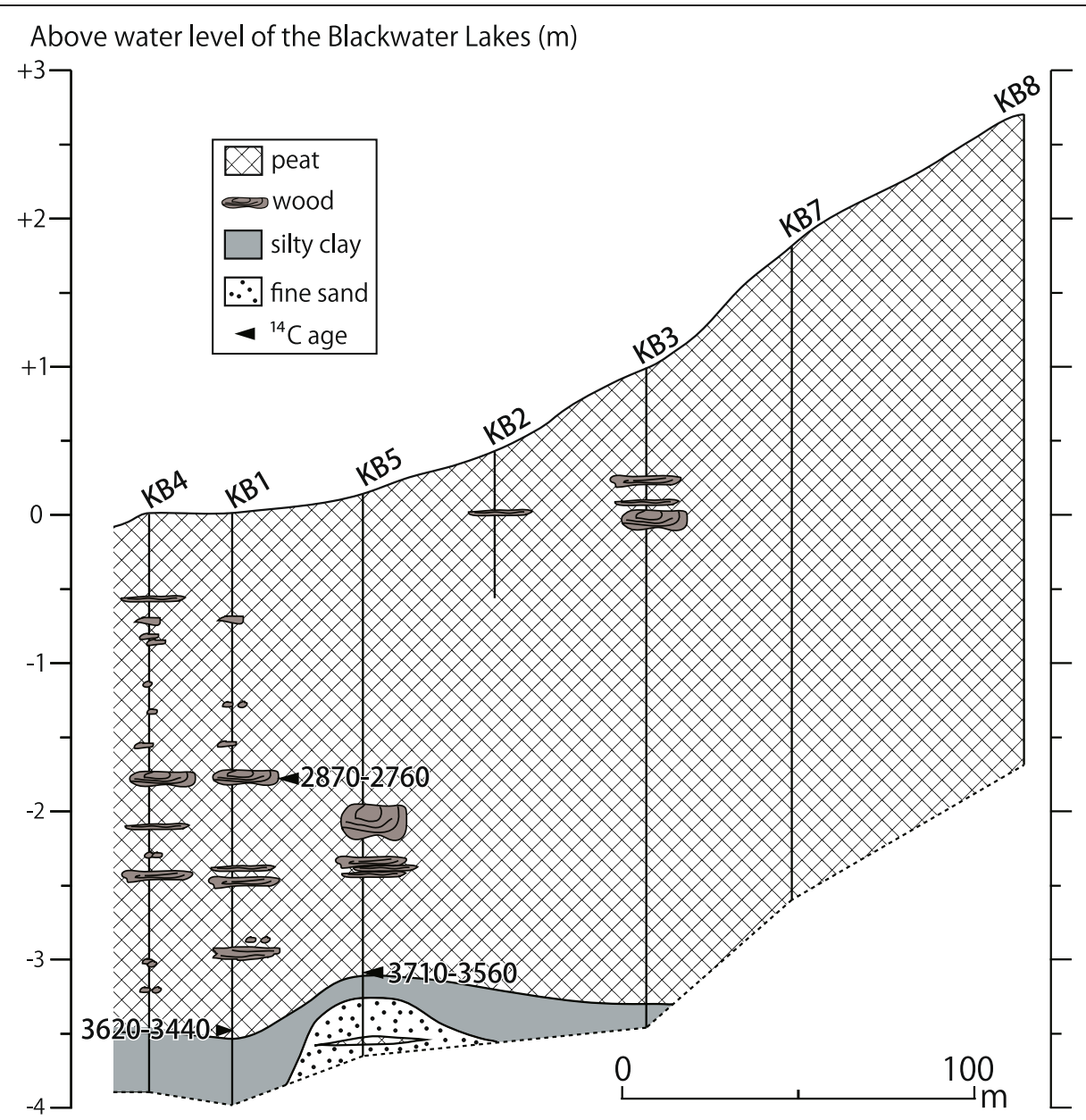

Figure 4 Simplified geological cross-section along a NW-SE transect, including the columnar sections of the cores. Coring sites are indicated in Figure 3.

into two groups: relatively high values in the middle part of the peat layer and relatively low values in the lower and upper parts.

The data on exchangeable cations exhibit strong variability through the core $\mathrm{KB} 1$, whereas the $\mathrm{C}$ content maintains high values from the depth of $3.5 \mathrm{~m}$ upwards. The exchangeable $\mathrm{Na}$ tends to decrease from around $3.5 \mathrm{~m}$ depth, whereas the exchangeable $\mathrm{K}$ remains constant between depths of 3.0 to $1.0 \mathrm{~m}$ and then increases abruptly above $1.0 \mathrm{~m}$. Furthermore, the exchangeable $\mathrm{Ca}$ fluctuates at high values, from $3.5 \mathrm{~m}$ to $1.0 \mathrm{~m}$ depth, and then decreases. The profile of exchangeable $\mathrm{Mg}$ has two peaks, at the $3.5-3.0 \mathrm{~m}$ and the $2.0-1.0 \mathrm{~m}$ depth.

\section{Discussion}

Fluvial facies and radiocarbon dating indicate that the sedimentary environment, in the study area, changed around 3,710-3,560 cal BP. Inorganic silty clay and fine sand have been carried by rivers, accumulating sago palm and grass remains in the shallow swamp waters. This phenomenon can also be described as a reduction of the Sanai and an expansion of the Pandago and

Table 1 Radiocarbon dating data

\begin{tabular}{|c|c|c|c|c|c|c|}
\hline Site & Depth (m) & Material & $\delta^{13} C(\%)$ & Conventional age (yrs BP) & $\begin{array}{l}\text { Calibrated age } \\
\text { (cal. BP with } 2 \sigma \text { age range) }\end{array}$ & Lab no (Beta-) \\
\hline \multirow[t]{2}{*}{ KB1 } & 1.8 & wood & -27.1 & $2,730 \pm 30$ & $2,870-2,760$ & 305430 \\
\hline & 3.5 & wood & -27.4 & $3,290 \pm 40$ & $3,620-3440$ & 305431 \\
\hline KB5 & 3.2 & peat & -19.3 & $3,390 \pm 40$ & $3,710-3,560$ & 305432 \\
\hline
\end{tabular}




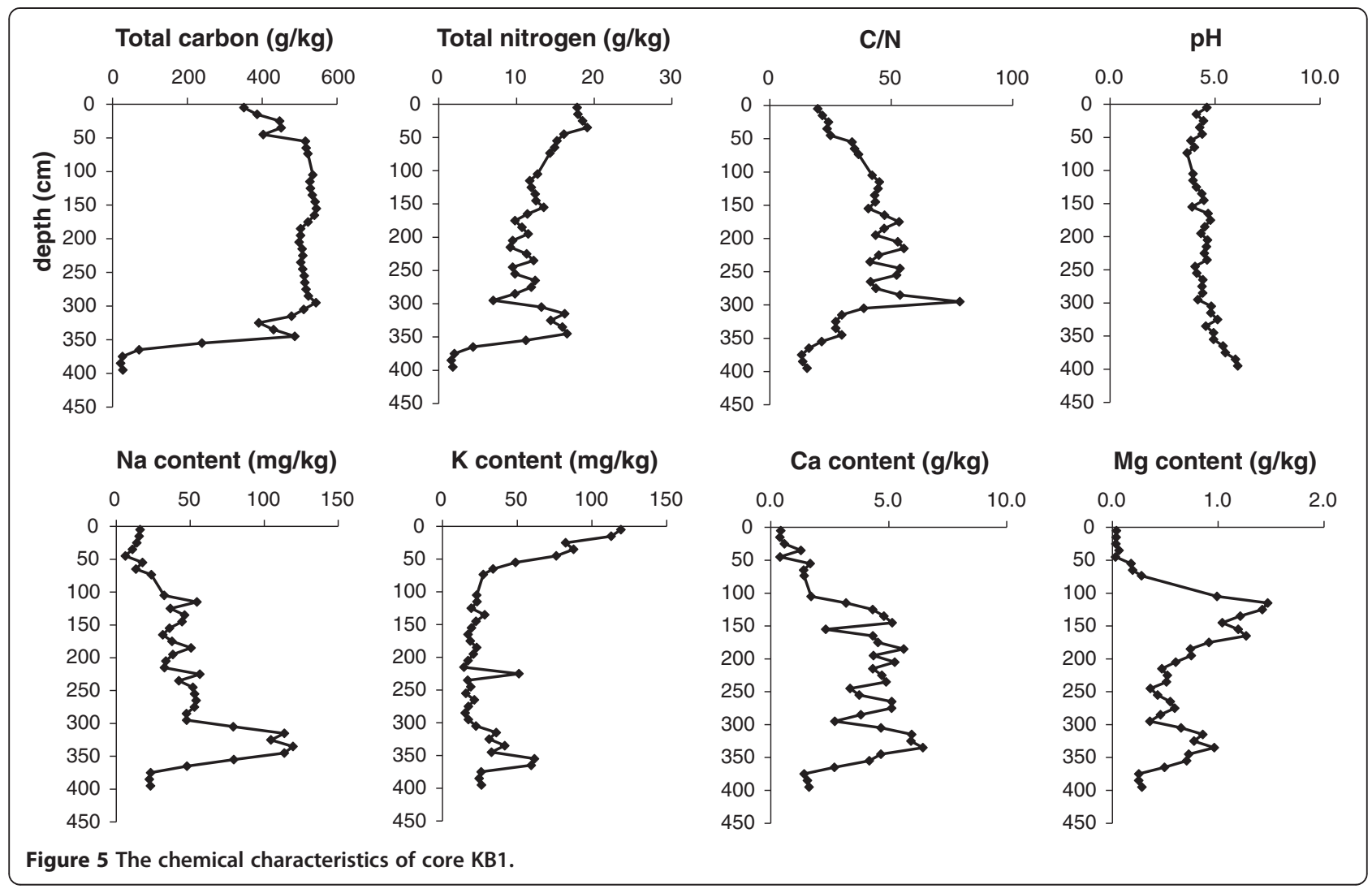

Kabuk components, possibly affecting the floodplains of middle Sepik. A mid-Holocene marine transgression followed by a late-Holocene marine regression occurred in the lower part of Sepik [12], inducing an expansion of the peat layer in the middle Sepik.

Important changes in the peat's chemical characteristics, between its different levels, were observed. The variation in the exchangeable cations' content is considered to correspond to a vegetation change in this area. Since the

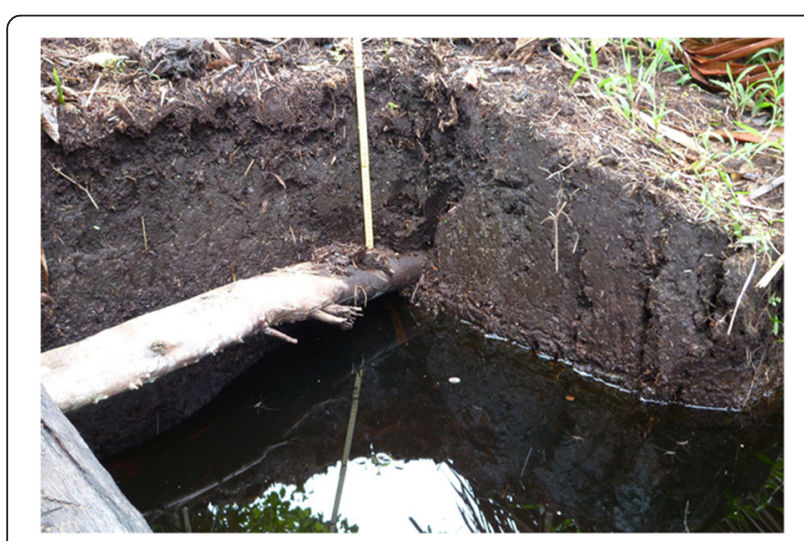

Figure 6 Outcrops of artificial watercourses in Kraimbit village. The photograph shows the upper part (about $30 \mathrm{~cm}$ ) of the peat layer. carbon content has remained at a high value from $3.5 \mathrm{~m}$ depth onwards, the area was probably covered with rich vegetation. However, the plant species assemblage might have changed. The $\mathrm{K}, \mathrm{Ca}$ and $\mathrm{Mg}$ content, in plant tissues, varies between the different species. The nutrient contents in various plant species from valleys in Ghana; in the 15 species analysed, the highest $\mathrm{Ca}$-content was measured at $27.0 \mathrm{~g} \mathrm{~kg}^{-1}$ in Mareya micrantha, with a K-content as low as $4.7 \mathrm{~g} \mathrm{~kg}^{-1}$, and the highest K-content was measured at $65.9 \mathrm{~g} \mathrm{~kg}^{-1}$ in Portulaca oleracea, corresponding to a low Ca-content of $4.6 \mathrm{~g} \mathrm{~kg}^{-1}$. Since their mobility in the peat layer varies among the elements, for example $\mathrm{K}$ and $\mathrm{Na}$ are more mobile than $\mathrm{Ca}$ and $\mathrm{Mg}$, the cation ratios in the peat do not directly reflect the contribution of the past vegetation [21]. However, the high values of exchangeable $\mathrm{Ca}$ and $\mathrm{Mg}$ in specific layers suggest that other plants coexisted in the area, along with sago palm.

\section{Conclusions}

Tropical peat was investigated in the middle Sepik Plain, northern Papua New Guinea. The thickness of the peat layers 3-4 $\mathrm{m}$, and the layers consist of partiallydecomposed organic matter and contain sago palm and grass remains within a very fine sand and clayey mineral matrix. Tropical peat formed between 3,710-3,560 cal $\mathrm{BP}$, as a result of a late-Holocene marine regression. 
The peat's chemical variability, especially regarding the exchangeable cations, may be due to a vegetation change in this area during the peat's formation.

Despite the limited nature of the presented data, with regard to the carbon storage issue, the results provided here constitute a significant contribution to this region's geological and geomorphological survey. The measured changes in the peat's chemical characteristics certainly demand additional studies to investigate further the factors affecting them, making use of existing research results on sago palm from other areas. Conclusively, the focus of future studies should be to widen the survey area and to analyse the peatlands' carbon storage parameters, including non-decomposed plant remains.

\section{Competing interests}

The authors declare that they have no competing interests.

\section{Authors' contributions}

All authors have jointly drafted the manuscript and participated in interpretation and have read and approved the final manuscript. Both EO and $\mathrm{MU}$ collected core samples from the study area. MU and TI conducted the chemical analysis of the peat samples. Prof. CT proposed some of the ideas for the interpretation of the chemical data. All authors read and approved the final manuscript.

\section{Acknowledgements}

We would like to thank Pamela Swadling and Robin Hide of Australian National Univ., Keichi Kumagai of Ochanomizu Univ., Kenichi Nonaka of Rikkyo Univ. and Mariko Shinmoto of Hiroshima Univ. This work was supported by JSPS KAKENHI Grant Number 22251002

\section{Author details \\ 'School of Education, Niigata University, 8050 Ikarashi-Ninocho, Nishi-ku, Niigata 950-2181, Japan. ${ }^{2}$ Graduate School of Bio-agricultural Sciences and School of Agricultural Sciences, Nagoya University Furo-cho, Chikusa-ku, Nagoya, Aichi 464-8601, Japan.}

Received: 8 October 2014 Accepted: 5 February 2015

Published online: 25 February 2015

\section{References}

1. Hooijer A, Page S, Canadell JG, Silvius M, Kwadijk J, Wösten H, Jauhiainen J (2010) Current and future $\mathrm{CO}_{2}$ emissions from drained peatlands in Southeast Asia. Biogeosciences 7:1505-1514, doi:10.5194/bg-7-1505-2010

2. Page SE, Rieley JO, Banks CJ (2011) Global and regional importance of the tropical peatland carbon pool. Glob Chang Biol 17:798-818, doi:10.1111/j.1365-2486.2010.02279.x

3. Page SE, Rieley JO, Shotyk W, Weiss D (1999) Interdependence of peat and vegetation in a tropical peat swamp forest. Philos Trans R Soc Lond B Biol Sci 354:1885-1897

4. Wüst RAJ, Bustin RM, Lavkulich L (2003) New classification systems for tropical organic-rich deposits based on studies of the Tasek Bera Basin, Malaysia. Catena 53:133-163, doi:10.1016/S0341-8162(03)00022-5

5. Page SE, Wüst RAJ, Weiss D, Rieley JO, Shotyk W, Limin SH (2004) A record of Late Pleistocene and Holocene carbon accumulation and climate change from an equatorial peat bog (Kalimantan, Indonesia): implications for past, present and future carbon dynamics. J Quat Sci 19:625-635, doi:10.1002/jqs.884

6. Dommain R, Couwenberg J, Joosten H. (2011) Development and carbon sequestration of tropical peat domes in South-East Asia: links to post-glacial sea-level changes and Holocene climate variability. Quat Sci Rev 30:999-1010. doi:0.1016/j.quascirev.2011.01.018

7. Shier CW (1985) Tropical peat resources - an overview. Proceedings of the Symposium on Tropical Peat Resources - Prospects and Potential. International Peat society, Helsinki, Kingston, Jamaica, pp 29-46
8. Wayi BM, Freyne DF (1992) The distribution, characterization, utilization and management of the peat soils in Papua New Guinea. In: Aminuddin BY, Tan SL (eds), Tropical Peat: Proceedings of the International Symposium on Tropical Peatland. Malaysian Agricultural Research and Development Institute, Kuching, Sarawak, Malaysia, 1991, pp 28-29

9. Haberle SG, Hope GS, der Kaars V (2001) Biomass burning in Indonesia and Papua New Guinea: natural and human induced fire events in the fossil record. Palaeogeogr Palaeoclimatol Palaeoecol 171:259-268, doi:0.1016/S0031-0182(01)00248-6

10. Hope G (2009) Environmental change and fire in the Owen Stanley Ranges, Papua New Guinea. Quat Sci Rev 28:2261-2276, doi:10.1016/j.quascirev.2009.04.012

11. Swadling P (1997) Changing shorelines and cultural orientations in the Sepik-Ramu, Papua New Guinea: Implications for Pacific prehistory. World Archaeol 29:1-14, doi:10.1080/00438243.1997.9980360

12. Chappell J (2005) Geographic changes of coastal lowlands in the Papuan past. In: Pawley A, Attenborough R, Golson J, Hide R (eds) Papuan Pasts: Cultural, Linguistic and Biological Histories of Papuan-Speaking Peoples. Pacific Linguistics, RSPAS, ANU, Canberra, pp 525-539

13. Chappell J (1993) Contrasting Holocene sedimentary geologies of lower Daly River, northern Australia, and lower Sepik-Ramu, Papua New Guinea. Sediment Geol 83:339-358, doi:10.1016/0037-0738(93)90020-6

14. Gascoigne I (1998) Papua New Guinea. Cavendish Square Publishing, New York

15. Löffler E (1977) Geomorphology of Papua New Guinea. CSIRO, ANU Press, Canberra

16. Haantjens HA, Reiner E, Robbins RG (1968) Land systems of the Wewak-lower Sepik area. In: Haantjens HA (ed) Lands of the Wewak-lower Sepik area, Territory of Papua and New Guinea. (CSIRO Land Use series 22). CSIRO, Melbourne, pp 15-48

17. Arnold JM (1968) Climate of the Wewak-lower Sepik area. In: Haantjens HA (ed) Lands of the Wewak-lower Sepik area, Territory of Papua and New Guinea. (CSIRO Land Use series 22). CSIRO, Melbourne, pp 49-60

18. Reiner E, Mabbutt A (1968) Geomorphology of the Wewak-lower Sepik area. In: Haantjens HA (ed) Lands of the Wewak-lower Sepik area, Territory of Papua and New Guinea. (CSIRO Land Use series 22). CSIRO, Melbourne, pp 61-71

19. Stuiver M, Reimaer PJ (1993) Extended ${ }^{14} \mathrm{C}$ database and revised CALIB radiocarbon calibration program. Radiocarbon 35:215-230

20. Reimer PJ, Baillie MGL, Bard E, Bayliss A, Beck JW, Bertrand CJH, Blackwell PG, Buck CE, Burr GS, Cutler KB, Damon PE, Edwards RL, Fairbanks RG, Friedrich M, Guilderson TP, Hogg AG, Hughen KA, Kromer B, McCormac G, Manning S, Bronk Ramsey C, Reimer RW, Remmele S, Southon JR, Stuiver M, Talamo S, Taylor FW, van der Plicht J, Weyhenmeyer CE (2004) IntCal04 terrestrial radiocarbon age calibration, 0-26 cal kyr BP. Radiocarbon 46:1029-1058

21. Annan-Afful E, Masunaga, Wakatsuki T (2005) Nutrient distribution in the profile of Valley bottom soils cultivated to rice in Ghana. J Plant Nutr 28:151-160, doi:10.1081/PLN-200042204

\section{Submit your manuscript to a SpringerOpen ${ }^{\circ}$ journal and benefit from:}

- Convenient online submission

- Rigorous peer review

- Immediate publication on acceptance

- Open access: articles freely available online

- High visibility within the field

- Retaining the copyright to your article

Submit your next manuscript at $>$ springeropen.com 